\title{
Randomized trial of suturing versus electrosurgical bipolar vessel sealing in abdominal hysterectomy
}

\author{
Sameer Darwade, Kishorkumar Hol, Sneha Trivedi, Gulab Singh Shekhawat*
}

Department of Obstetrics and Gynecology, Smt. Kashibai Navale Medical College, Narhe, Ambegaon, Pune-411041, Maharashtra, India

Received: 07 May 2016

Accepted: 23 May 2016

\section{*Correspondence:}

Dr. Gulab Singh Shekhawat,

E-mail: gsshekhawata@yahoo.co.in

Copyright: (c) the author(s), publisher and licensee Medip Academy. This is an open-access article distributed under the terms of the Creative Commons Attribution Non-Commercial License, which permits unrestricted non-commercial use, distribution, and reproduction in any medium, provided the original work is properly cited.

\section{ABSTRACT}

Background: Hemorrhage is one of the most frequent complications that occur during surgery, adequate hemostatic techniques are essential during surgical procedures. The aim of this study was to compare the conventional suturing with the bipolar clamping and the effects of bipolar vessel sealing in women undergoing total abdominal hysterectomy.

Methods: A randomized controlled trial was performed at Smt. Kashibai Navale Medical College and General Hospital, Maharashtra, India. One hundred fourteen patients undergoing abdominal hysterectomy for benign conditions were randomized to conventional surgery versus vessel sealing followed up for 06 weeks post operatively. Results: During the first two postoperative days patients operated using bipolar vessel sealing had statistically significantly lower pain scores and blood loss $(\mathrm{p}<0.01)$. The surgery time, complication risk and duration of hospitalization were similar between both groups. Patients in the bipolar vessel sealing group resumed their normal daily activities on average 6 days earlier as compared to the conventional group $(p=0.07)$. Postoperative pelvic floor function was similar in both the groups.

Conclusions: The use of bipolar vessel sealing during abdominal hysterectomy for benign conditions appears to be associated with reduced blood loss, postoperative pain and faster recovery.

Keywords: Abdominal hysterectomy, Bipolar vessel sealing system, Post-operative, Hemostatic techniques

\section{INTRODUCTION}

Hemorrhage is one of the most frequent complications that occur during surgery, adequate hemostatic techniques are essential during surgical procedures. The method of vessel sealing relies on the application of a precise amount of bipolar electrocoagulation and pressure to the tissue, leading to the denaturation of the collagen and elastin in vessel walls, resulting in a hemostatic seal. ${ }^{1,2}$ The technique is able to seal vessels of up to $7 \mathrm{~mm}$ in diameter and the seal can with stand a maximum of three times the normal systolic pressure. Several studies reported a decrease in operating time or operative blood loss using vessel-sealing devices in comparison to conventional suturing. ${ }^{3-5}$ It also hypotheses that cutting the supportive ligaments as close to the uterus as possible during simple hysterectomy by bipolar vessel sealing clamp might well reduce autonomic nerve damage, thus resulting in improved postoperative pelvic floor functions.

The reduced postoperative pain may be explained by the fact that the amount of traction applied to the tissue, during operation, is reduced when using vessel sealing. In the Department of Obstetrics and Gynecology, Smt. Kashibai Navale Medical College, Pune, Maharashtra, India conducted the controlled trial comparing the effects of bi polar vessel sealing clamp versus conventional suturing in abdominal hysterectomy on operative time, blood loss, post-operative pain and pelvic floor dysfunctions.

The aim of the study was to compare blood loss, postoperative pain, morbidity and postoperative pelvic 
floor function between both groups. An intention to treat analysis was performed.

\section{METHODS}

The study includes 120 patients of age $\geq 35$ years old who were scheduled for abdominal hysterectomy with or without salpingo-oophorectomy for a benign disorder at SKN Medical College \& General Hospital between January 2013 and January 2016 included in the study after giving written informed consent. We followed up 114 patients up to 06 weeks postoperatively. Out of 120 recruited patients 06 patients dint not show up. Patients were excluded from study if a malignancy was suspected or if one of the ovaries exceeded a diameter of $10 \mathrm{~cm}$, or if additional surgical procedures during the same operation were planned. All patient data, including the registration of complications during a follow-up period of 6 weeks, were recorded for analysis.

\section{Randomization}

Patients were assigned randomly to have abdominal hysterectomy by conventional clamping and suturing or by vessel sealing. The randomization code was developed by using a computerized random number generator.

\section{Surgical procedures}

Bipolar electrosurgical re-usable clamp was used in open surgery applications in 56 patients for ligation of pedicles i.e. the permanent sealing of vascular bundles and tissues in areas of surgery. The ligation operation is a device stimulated by a Nova Chimco, Mumbai India, and generates with a standard setting between 30 and $40 \mathrm{~W}$. The device can seal vessels measuring up to $7 \mathrm{~mm}$. The safety necessities are fulfilled, owing to the ability of the sealed ends of the device to withstand almost $700 \mathrm{~mm} \mathrm{Hg}$ of pressure. This device has marginal thermal side-effect of $1 \mathrm{~mm}$, which is attributed to the unique sandwich structure of the instrument. The Nova Chimco generator was used in combination with bipolar clamps. The used settings of the generator were completely automatic implicating a standard setting of 2 bars, and a sealing time of 4 to 7 seconds. The amount of blood loss was measured by adding the measured blood loss volume by a suction device to the measured volume in weighted gauzes.

Conventional total abdominal hysterectomy was performed in 58 patients according to a standardized technique. All ligaments were clamped, transacted and sutured or ligated using \#01 vicryl sutures.

\section{Peri-operative care}

Peri-operative treatment was similar in both participating hospitals. A 14-French Foley indwelling bladder catheter with a $10 \mathrm{ml}$ balloon was placed in all women postoperatively and removed after approximately 24 hours. Pharmacologic postoperative pain management was similar in all patients. Within these limits they were free to decide how much pain medication they took. Both the patients and the nurses were blinded for the type of surgery that had been performed. When patients were dismissed from hospital, a similar advice was given. Patients were allowed to resume activities after the operation whenever they felt comfortable and able to do so.

\section{Outcome measurements}

Primary outcome was postoperative pain, measured at a visual analogue scale. Pain scores were completed daily during the first postoperative week, second and sixth weeks after surgery. Secondary outcomes were duration of surgery, amount of blood loss, complications during surgery, complications during hospital stay, duration of hospital stay, late complications related to surgery, experienced discomfort related to surgery, ability to perform normal daily activities, time to resume normal daily activities (in days), disease specific quality of life (quality of life related to micturition and defecation) and general quality of life.

All patients were asked to complete the following disease specific quality of life questionnaires before surgery and at 6 weeks after surgery.

Table 1: Questionnaire before surgery and 6 weeks of after surgery.

\section{Questionnaire}

The urogenital distress inventory (UDI Range 0-100)

This questionnaire assesses the presence and experienced bother of pelvic floor symptoms. UDI scores range from 0100,0 identifying patients without any symptoms present and 100 identifying patients who encounter all possible symptoms and experience these all as maximal bothersome. Symptoms measured with the UDI are divided into five domains, namely: discomfort/pain, urinary incontinence, overactive bladder, genital prolapse and obstructive micturition.

The defecation distress inventory (DDI Range 0-100)

This questionnaire assesses the presence and experienced bother of defecation symptoms. 0 identifying patients without any symptoms present and 100 identifying patients who encounter all possible symptoms and experience these all as maximal bothersome.

\section{A visual analogue scale (VAS range 0 to 100 )}

To assess the experienced pain was filled in daily during the first week after surgery and 2 and 6 weeks thereafter by all patients.

\section{Statistical analysis}

Statistical analysis was performed using SPSS 14.0 software. A p-value $<0.05$ was considered to be statistically significant. In case of multiple comparisons this value was corrected accordingly. 


\section{RESULTS}

A total of 114 patients participated in the randomized trial. Vessel sealing was used in 56 women and the remaining 58 women underwent conventional surgery using clamps and sutures. The questionnaire before and after 06 weeks of surgery was completed by all 114 patients.

Table 2: Baseline characteristics of patients undergoing abdominal hysterectomy assigned to conventional surgery and to bipolar vessel sealing.

\begin{tabular}{|c|c|c|}
\hline & $\begin{array}{l}\text { Conventional } \\
(\mathrm{n}=58)\end{array}$ & $\begin{array}{l}\text { Vessel } \\
\text { sealing } \\
(\mathrm{n}=56)\end{array}$ \\
\hline Age (years) & $4 \pm 2.4$ & $44 \pm 2.6$ \\
\hline BMI $\left(\mathrm{kg} / \mathrm{m}^{2}\right)$ & $26 \pm 3.5$ & $28 \pm 3.3$ \\
\hline Parity & 2.5 & 2.7 \\
\hline $\begin{array}{l}\text { No }(\%) \text { with co } \\
\text { morbidity }\end{array}$ & $14(24.13 \%)$ & $16(28.57 \%)$ \\
\hline Hypertension & 5 & 6 \\
\hline COPD & 1 & 2 \\
\hline Thyroid disorders & 2 & 3 \\
\hline Diabetes & 3 & 2 \\
\hline Depressive & 2 & 2 \\
\hline $\begin{array}{l}\text { symptoms } \\
\text { Other }\end{array}$ & 1 & 1 \\
\hline $\begin{array}{l}\text { No }(\%) \text { with } \\
\text { history of surgery }\end{array}$ & $12(20.68 \%)$ & $18(32 \%)$ \\
\hline Cesarean section & 1 & 3 \\
\hline Sterilisation & 4 & 4 \\
\hline Curettage & 2 & 1 \\
\hline Adnexal surgery & 3 & 3 \\
\hline Myoma enucleation & 1 & 2 \\
\hline $\begin{array}{l}\text { Diagnostic } \\
\text { laparoscopy }\end{array}$ & 1 & 5 \\
\hline \multicolumn{3}{|l|}{$\begin{array}{l}\text { No }(\%) \text { with } \\
\text { indication for } \\
\text { hysterectomy }\end{array}$} \\
\hline Menorrhagia & $26(44.8 \%)$ & $30(54 \%)$ \\
\hline Metrorrhagia & $4(6.89 \%)$ & $8(14 \%)$ \\
\hline Dysmenorrhoea & $4(6.89 \%)$ & $0(0 \%)$ \\
\hline $\begin{array}{l}\text { Mechanical } \\
\text { discomfort }\end{array}$ & $16(27.58 \%)$ & $16(29 \%)$ \\
\hline $\begin{array}{l}\text { Chronic abdominal } \\
\text { pain }\end{array}$ & $8(13.79 \%)$ & $4(7 \%)$ \\
\hline $\begin{array}{l}\text { Duration of } \\
\text { symptoms (months) }\end{array}$ & $19 \pm 5.5$ & $18 \pm 4.3$ \\
\hline $\begin{array}{l}\text { Largest diameter of } \\
\text { uterus }(\mathrm{cm})\end{array}$ & $11 \pm 4.4$ & $11 \pm 3.4$ \\
\hline
\end{tabular}

Patient characteristics were similar between both treatment arms (Table 2), except for previous surgical procedures being more common in the vessel sealing group. Repeated measurements analysis showed that during the first 3 days after surgery postoperative pain was statistically significantly higher in the conventional group than in the vessel sealing group (Table 3). From day 4 to day 7 after surgery, the conventional group still reported more pain although the difference was no longer statistically significant. Pains scores of second and sixth weeks after surgery were similar for both interventions.
Table 3: Comparison of pain and daily activity scores after surgery.

\begin{tabular}{|c|c|c|c|}
\hline & $\begin{array}{l}\text { Conventional } \\
(\mathrm{n}=58)\end{array}$ & $\begin{array}{l}\text { Vessel } \\
\text { sealing } \\
(n=46)\end{array}$ & $\begin{array}{l}\mathrm{p}- \\
\text { value }\end{array}$ \\
\hline $\begin{array}{l}\text { VAS pain } \\
\text { score }(0-100)\end{array}$ & mean $(\mathrm{SE})$ & mean $(\mathrm{SE})$ & \\
\hline $\begin{array}{l}\text { Evening after } \\
\text { surgery }\end{array}$ & $68(4)$ & $52(5)$ & \\
\hline $\begin{array}{l}\text { Day } 1 \text { after } \\
\text { surgery }\end{array}$ & $62(3)$ & $48(5)$ & $<0.01$ \\
\hline $\begin{array}{l}\text { Day } 2 \text { after } \\
\text { surgery }\end{array}$ & $48(4)$ & $34(4)$ & \\
\hline $\begin{array}{l}\text { Day } 3 \text { after } \\
\text { surgery }\end{array}$ & $40(4)$ & $28(4)$ & 0.38 \\
\hline $\begin{array}{l}\text { Day } 4 \text { after } \\
\text { surgery }\end{array}$ & $34(4)$ & $27(4)$ & 0.77 \\
\hline $\begin{array}{l}\text { Day } 5 \text { after } \\
\text { surgery }\end{array}$ & $32(4)$ & $21(3)$ & \\
\hline $\begin{array}{l}\text { Day } 6 \text { after } \\
\text { surgery }\end{array}$ & $26(4)$ & $23(4)$ & \\
\hline $\begin{array}{l}\text { Day } 7 \text { after } \\
\text { surgery }\end{array}$ & $22(4)$ & $19(3)$ & \\
\hline $\begin{array}{l}2 \text { weeks after } \\
\text { surgery }\end{array}$ & $17(3)$ & $15(4)$ & \\
\hline $\begin{array}{l}6 \text { weeks after } \\
\text { surgery }\end{array}$ & $11(3)$ & $10(3)$ & \\
\hline $\begin{array}{l}\text { DAS score }(0- \\
100)\end{array}$ & mean $(\mathrm{SE})$ & mean $(\mathrm{SE})$ & \\
\hline $\begin{array}{l}\text { Before } \\
\text { surgery }\end{array}$ & $34(3)$ & $33(2)$ & \\
\hline $\begin{array}{l}1 \text { week after } \\
\text { surgery }\end{array}$ & $66(3)$ & $62(4)$ & 0.83 \\
\hline $\begin{array}{l}2 \text { weeks after } \\
\text { surgery }\end{array}$ & $55(3)$ & $60(4)$ & \\
\hline $\begin{array}{l}6 \text { weeks after } \\
\text { surgery }\end{array}$ & $44(3)$ & $43(3)$ & \\
\hline $\begin{array}{l}\text { Days to return } \\
\text { to normal } \\
\text { daily activity }\end{array}$ & $34(3)$ & $24(2)$ & 0.07 \\
\hline
\end{tabular}

Administered pain medication and the experienced bother directly related to the surgery were similar in both groups.

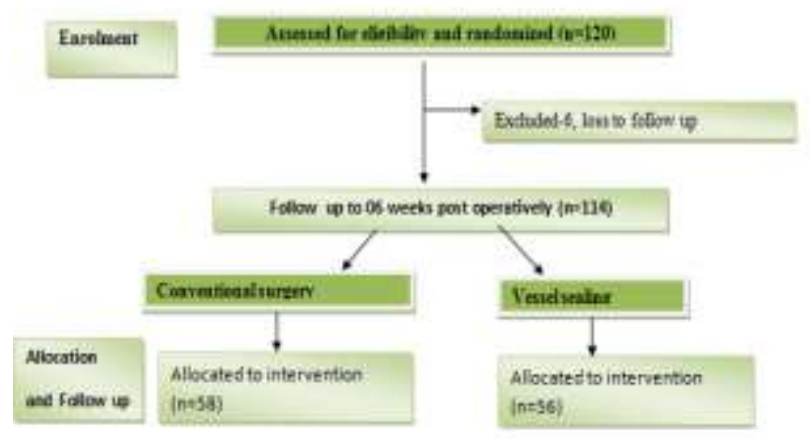

Figure 1: Consort flow chart of participants through each stage of trial. 
Table 4: Comparison of surgical outcomes.

\begin{tabular}{|c|c|c|c|}
\hline & Conventional $(\mathrm{n}=58)$ & Vessel sealing $(\mathrm{n}=\mathbf{5 6})$ & p- value \\
\hline $\begin{array}{l}\text { Total operating time from initial skin } \\
\text { incision till final skin closure (min) }\end{array}$ & $62(38-124)$ & $56(29-130)$ & 0.62 \\
\hline Blood loss in $\mathrm{mL}$ & $330(70-750)$ & $180(33-500)$ & 0.05 \\
\hline Hospitalisation in days & $5(4-9)$ & $4(2-11)$ & 0.26 \\
\hline Per-operative complications & $3(5.17 \%)$ & $3(5.21 \%)$ & 0.96 \\
\hline Bleeding $>1000 \mathrm{ml}$ & 3 & 2 & \\
\hline Bladder lesion & 0 & 1 & \\
\hline Post-operative complications & $3(5.17 \%)$ & $2(3.5 \%)$ & 0.96 \\
\hline Ileus requiring re-operation & 1 & 1 & \\
\hline Infected haematoma & 1 & 1 & \\
\hline Wound dehiscence & 1 & 0 & \\
\hline
\end{tabular}

Table 5: Group comparison of urogenital distress inventory and defecation distress inventory domain scores.

\begin{tabular}{|lllll|}
\hline & $\begin{array}{l}\text { Before surgery } \\
\text { Conventional } \\
(\mathrm{n}=58)\end{array}$ & $\begin{array}{l}\text { Vessel sealing } \\
(\mathrm{n}=56)\end{array}$ & $\begin{array}{l}\text { Six weeks after surgery } \\
\text { Conventional } \\
(\mathrm{n}=58)\end{array}$ & $\begin{array}{l}\text { Vessel sealing } \\
(\mathrm{n}=56)\end{array}$ \\
\hline UDI & mean (SE) & mean (SE) & mean (SE) & mean (SE) \\
\hline Overactive bladder & $14(5)$ & $16(6)$ & $15(5)$ & $18(5)$ \\
Urinary incontinence & $9(3)$ & $9(3)$ & $12(4)$ & $8(3)$ \\
Obstructive micturition & $5(3)$ & $12(4)$ & $13(5)$ & $11(4)$ \\
Discomfort & $14(3)$ & $6(2)$ & $8(3)$ & $3(2)$ \\
Genital prolapse & $5(3)$ & $9(5)$ & $2(1)$ & mean (SE) \\
\hline DDI & mean (SE) & mean (SE) & mean (SE) & $6(3)$ \\
\hline Obstipation & $6(4)$ & $7(4)$ & $6(3)$ & $4(2)$ \\
Obstructive defecation & $3(2)$ & $6(2)$ & $4(2)$ & $7(4)$ \\
Discomfort & $3(3)$ & $7(3)$ & $5(2)$ & $3(1)$ \\
Fecal incontinence & $3(2)$ & $2(1)$ & $1(0)$ & $11(5)$ \\
Flatulence & $4(4)$ & $8(4)$ & $7(3)$ & \\
\hline
\end{tabular}

$\mathrm{SE}=$ standard error, UDI $=$ Urogenital distress inventory, DDI $=$ Defecation distress inventory.

No statistically significant differences in DAS scores were observed between both groups. Table 4 shows a comparison of surgical parameters between both groups.

Significant differences in operation time and complications were not observed although a trend was observed towards less blood loss in the vessel sealing group. None of the complications in the vessel sealing group could be directly linked to the use of the device.

The mean time to resume daily activities was 8.4 days shorter for women in the vessel sealing group as compared to the conventional group $(\mathrm{p}=0.07)$. There were no significant differences observed between both groups in any of the compared UDI and DDI domain scores (Table 5). A per surgeon analysis showed that the outcomes of less and more experienced surgeons were also similar.

\section{DISCUSSION}

Hemorrhage is frequently associated with postoperative pain. ${ }^{1}$ We could not identify a significant difference in mean operating time between the bipolar cutting device and the conventional suturing, even after correction for possible confounding parameters.

According to Thakar $\mathrm{R}$ et al, urination was more than seven times during the day (33 percent in the subtotalhysterectomy group and 31 percent in the totalhysterectomy group before surgery). ${ }^{6}$

Hagen $S$ et al reports that intervention women had significantly greater improvement than controls in prolapse symptoms (mean score decrease 3.5 versus 0.1 , $\mathrm{p}=0.021$ ), were significantly more likely to have an improved prolapse stage $(45 \%$ versus $0 \%, \mathrm{p}=0.038)$ and were significantly more likely to say their prolapse was better $(63 \%$ versus $24 \%, \mathrm{p}=0.012){ }^{7}$ 
According to Uebersax JS et al incontinence impact questionnaire (IIQ) and the urogenital distress inventory (UDI). These instruments assess life impact and symptom distress, respectively, of urinary incontinence and related conditions for women. All subsets regression analysis was used to find item subsets that best approximated scores of the long form versions. The approach succeeded in reducing the 30-item IIQ and the 19-item UDI to 7and 6-item short forms, respectively and whereas van der Vaart $\mathrm{CH}$ et al reports that prevalence of urinary incontinence is higher than usually reported. Especially the urge component affects the quality of life in a negative way. 8,9

Thakar $\mathrm{R}$ et al reports that detrimental effects on urinary, bowel or sexual function will continue to be for some women after appropriate treatment. ${ }^{10}$ Dyspareunia, libido and the number of orgasms were evaluated as disorders affecting sexual life. At follow-up 12 months postoperatively a statistically significant decrease in stress incontinence, frequency and nocturia was observed according to Virtanen $\mathrm{H}$ et al. ${ }^{11}$

According to Butler-Manuel SA et al significantly more autonomic nerves are transected in the more lateral division of the uterine supporting ligaments during a radical hysterectomy than during a simple hysterectomy and Heniford BT et al reported Suture ligatures, ties, hemoclips, and other ligating techniques were used rarely $(0.3 \%)$ after an application of the EBVS. In an experimental animal model, the EBVS was significantly faster and more efficient. ${ }^{12,13}$

Kennedy JS et al also reported that ultrasonic and bipolar occlusions were significantly less likely to have burst strengths greater than $400 \mathrm{mmHg}$ as compared with seals, clips, and ligatures $(\mathrm{p}<0.001) .^{14}$

However the peri operative blood loss was less with bipolar sealing clamp. It was shown that postoperative pain was less if vessel sealing was used and this group of patients also needed shorter time to resume normal daily activities. Duration of surgery, hospital stay, complication rate and postoperative pelvic floor function were similar in both groups. In this study both peroperative and postoperative complications were similar in both groups.

It was observed that the physicians who performed the majority of the procedures had on average less blood loss when using vessel sealing as compared to using conventional technique. Based on this observation it may be possible that after a short learning curve using vessel sealing could be faster and safer.

Landman $\mathrm{J}$ et al also reports that in the porcine model ligasure system is a viable option for laparoscopic management of arteries and veins. ${ }^{15}$
We think that an additional explanation is that during vessel sealing traction to the tissue and autonomic innervations surrounding the uterus is avoided as the clamps rather push in the opposite direction as they pull during conventional surgery.

\section{CONCLUSION}

In conclusion, patients undergoing abdominal hysterectomy for benign disease appear to benefit of the use of a vessel sealing technique, which reduces postoperative pain in comparison to the conventional surgical technique using suturing.

\section{Funding: No funding sources}

Conflict of interest: None declared

Ethical approval: The study was approved by the Institutional Ethics Committee

\section{REFERENCES}

1. Jayne DG, Botterill I, Ambrose NS, Brennan TG, Guillou PJ, O'Riordain DS. Randomized clinical trial of ligasure versus conventional diathermy for day-case haemorrhoidectomy. $\mathrm{Br}$ J Surg. 2002;89(4):428-32.

2. Palazzo FF, Francis DL, Clifton MA. Randomized clinical trial of ligasure versus open haemorrhoidectomy. Br J Surg. 2002;89(2):154-7.

3. Takada M, Ichihara T, Kuroda Y. Comparative study of electrothermal bipolar vessel sealer and ultrasonic coagulating shears in laparoscopic colectomy. Surg Endosc. 2005;19(2):226-8.

4. Hagen B, Eriksson N, Sundset M. Randomised controlled trial of ligasure versus conventional suture ligature for abdominal hysterectomy. BJOG. 2005;112(7):968-70.

5. Roovers JP, van der Bom JG, van der Vaart $\mathrm{CH}$, Heintz AP. Hysterectomy and sexual wellbeing: prospective observational study of vaginal hysterectomy, subtotal abdominal hysterectomy, and total abdominal hysterectomy. BMJ. 2003;327(7418):774-8.

6. Thakar R, Ayers S, Clarkson P, Stanton S, Manyonda I. Outcomes after total versus subtotal abdominal hysterectomy. $\mathrm{N}$ Engl J Med. 2002;347(17):1318-25.

7. Hagen S, Stark D, Glazener C, Sinclair L, Ramsay I. A randomized controlled trial of pelvic floor muscle training for stages I and II pelvic organ prolapse. Int Urogynecol J Pelvic Floor Dysfunct. 2009;20(1):4551.

8. Uebersax JS, Wyman JF, Shumaker SA, McClish DK, Fantl JA. Short forms to assess life quality and symptom distress for urinary incontinence in women: the incontinence impact questionnaire and the urogenital distress inventory. continence program for women research group. Neurourol Urodyn. 1995;14(2):131-9. 
9. van der Vaart CH, de Leeuw JR, Roovers JP, Heintz AP. The influence of urinary incontinence on quality of life of community-dwelling, 45-70 year old Dutch women. Ned Tijdschr Geneeskd. 2000;144(19):8947.

10. Thakar R, Manyonda I, Stanton SL, Clarkson P, Robinson G. Bladder, bowel and sexual function after hysterectomy for benign conditions. Br J Obstet Gynaecol. 1997;104(9):983-7.

11. Virtanen $H$, Makinen J, Tenho $T$, Kiilholma $P$, Pitkanen Y, Hirvonen T. Effects of abdominal hysterectomy on urinary and sexual symptoms. Br J Urol. 1993;72(6):868-72.

12. Butler-Manuel SA, Buttery LD, A'Hern RP, Polak JM, Barton DP. Pelvic nerve plexus trauma at radical hysterectomy and simple hysterectomy: the nerve content of the uterine supporting ligaments. Cancer. 2000;89(4):834-41.

13. Heniford BT, Matthews BD, Sing RF, Backus C, Pratt B, Greene FL. Initial results with an electrothermal bipolar vessel sealer. Surg Endosc. 2001;15(8):799-801.

14. Kennedy JS, Stranahan PL, Taylor KD, Chandler JG. High-burst-strength, feedback-controlled bipolar vessel sealing. Surg Endosc. 1998;12(6):876-8.

15. Landman J, Kerbl K, Rehman J, Andreoni C, Humphrey PA, Collyer W, et al. Evaluation of a vessel sealing system, bipolar electro-surgery, harmonic scalpel, titanium clips, endoscopic gastrointestinal anastomosis vascular staples and sutures for arterial and venous ligation in a porcine model. J Urol. 2003;169(2):697-700.

Cite this article as: Darwade $\mathrm{S}, \mathrm{Hol} \mathrm{K}$, Trivedi $\mathrm{S}$, Shekhawat G. Randomized trial of suturing versus electrosurgical bipolar vessel sealing in abdominal hysterectomy. Int J Reprod Contracept Obstet Gynecol 2016;5:1778-83. 